\title{
inovação de produto ou saída para a crise? \\ - lançamento da cerveja brahma chopp no verão de 1934
}

Teresa Cristina de Novaes Marques

Faculdade União Pioneira de Integração Social

Maria Teresa Ribeiro de Oliveira

Universidade de Brasília

\section{RESUMO}

Este ensaio explora a história da indústria da cerveja, um produto de largo consumo no Brasil. Em particular, examina a história de uma marca - a Brahma Chopp - ainda hoje lembrada pelos apreciadores da bebida. Exaltada na propaganda de seu lançamento como uma inovação, fruto de investimento tecnológico, o surgimento da nova marca representou, por um lado, uma resposta da empresa à expressiva queda nas vendas sentida desde o início da crise econômica no segundo semestre de 1929. Por outro lado, indicou a profunda reformulação da imagem pública da Brahma, encerrando um processo de nacionalização em curso desde meados da Primeira Guerra. Assim, a partir de um caso exemplar de produto de sucesso, examinamos um conjunto de problemas pertinentes à história da indústria de bens de consumo no Brasil: os efeitos duradouros da Guerra, o impacto da crise dos anos 1930 sobre essa indústria, a competição no mercado de cerveja na cidade do Rio de Janeiro e, por fim, o papel da propaganda na consolidação econômica e simbólica de uma empresa.

Palavras-chave: cerveja, crise econômica, indústria de bens de consumo,propaganda, marcas.

\begin{abstract}
This essay examines the history of Brazil's beer industry with a particular focus on one of its best known trademarks, Brahma Chopp. Presented by the advertising campaign made at the time of its launching as a product innovation, the new brand of beer represented, on one hand, an answer of Brahma Co. to the consummer market crisis brought by the 1929 crash. On the other hand, the advertising campaign reflected the process of Brahmas public image nationalization. Founded as a German owned enterprise in the of nineteenth century, the company felt the pressures of the anti German public opinion mood during the First World War. By studying Brahma Chopps success, we examine a set of issues related to the history of consummer goods industry in Brazil: the long lasting political effects of the War, the impact of the 1929 crisis on that industry, competition in the beer market of Rio de Janeiro, and the role played by marketing and advertising in the economic and symbolic affirmation of an enterprise in its market.
\end{abstract}

Key words: beer, crisis, consumer goods industry, advertisement, trademarks.

'Este trabalho constitui uma versão melhorada do capítulo VII da tese de doutorado de Teresa Cristina Novaes Marques (2003) Capital, Cerveja e Consumo de Massa: a trajetória da Brahma, 1888-1933, Universidade de Brasília, cuja elaboração muito se beneficiou da leitura crítica feita por Elizabeth Cancelli, orientadora da tese. A Hildete Pereira de Melo e a José Luciano de Mattos Dias as autoras agradecem as críticas e comentários, que lhes permitiram aprimorar seu trabalho. 


\section{História de empresas e a história de produtos}

Muitos consumidores parecem acreditar que os produtos que fazem parte de seu cotidiano sempre estiveram disponíveis, e não se dão conta de que eles têm uma história, uma origem e uma razão para terem sido criados.

Este ensaio investiga as circunstâncias históricas do surgimento de uma nova marca de cerveja no Brasil: a Brahma Chopp, em 1934. ${ }^{2}$ Uma marca que buscava associar o prestígio já conquistado das cervejas Brahma com o apelo do chope, uma bebida de grande consumo durante os meses de verão nos espaços públicos de lazer da cidade. E uma cerveja que não era um produto qualquer, indiferenciado, como uma peça de tecido ordinário, por exemplo. A disseminação de seu consumo exigia estratégias para persuadir os consumidores dos seus atributos. No início do século XX, ainda não havia uma demanda significativa por cerveja no Brasil. Daí as cervejarias empregarem recursos variados - inclusive a propaganda - para persuadir os consumidores a preferirem cerveja a outras bebidas alcoólicas.

As ações promovidas pela empresa em 1934 para lançar a Brahma Chopp buscavam construir uma nova marca, e, na escolha das estratégias comerciais para promoção do produto, a propaganda teve lugar de destaque. Também foram implementadas outras formas de intervenção no mercado, complementares à propaganda, como: financiar o estabelecimento de locais de venda exclusiva, condicionar o fornecimento dos velhos produtos à compra dos novos, além do pagamento de comissões a garçons e a propagandistas. Tais artifícios pretendiam ampliar as vendas de cerveja e consolidar a presença das marcas da empresa no meio consumidor.

A escolha do objeto da nossa investigação se justifica porque acreditamos ser parcial a compreensão da história das empresas sem a consideração da história de seus produtos. Como, ao investigar a história de

\footnotetext{
De acordo com Wolfgang F. Haug (1997), Crítica da Estética da Mercadoria, São Paulo: UNESP, a marca é uma estetização da mercadoria. A propaganda que promove uma marca apresenta a mercadoria ao consumidor sob o invólucro de camadas simbólicas (a estética, o formato do produto), que obstruem a visão do conteúdo de trabalho social presente no objeto.Trata-se, portanto, de um discurso ideológico. Em termos operacionais, a construção de uma marca — isto é, o processo de afirmação simbólica de uma mercadoria no mercado - torna único e revestido de identidade o produto de massa, produzido em larga escala e indiferenciado. Se a operação comercial e ideológica for bem sucedida e os consumidores se tornarem fiéis a uma dada marca, então seu produtor poderá sustentar um preço de monopólio.
} 
um produto, acabamos deparando com a questão do papel da propaganda na construção simbólica de uma marca comercial, devemos abordar o assunto também em seus aspectos culturais. Isso é particularmente necessário na história da indústria cervejeira no Brasil, pois, no seu desenvolvimento, empresas e produtos têm histórias que se complementam.

Marcas, propaganda e mercadorias pertencem a um fenômeno social maior, que é o ato de consumir. O ato do consumo implica, necessariamente, por parte do consumidor, fazer escolhas econômicas e simbólicas, sendo, portanto, também, uma operação cultural. Essa característica deve ser levada em conta quando buscamos explicações satisfatórias para o papel que a propaganda exerce na indução ao consumo, algo que nem sempre tem sido considerado na literatura. Ora vemos estudos, como o de Carl Miller, que fazem leituras ingênuas da propaganda e tomam o conteúdo das mensagens de forma acrítica, ${ }^{3}$ ora encontramos leituras conspiratórias da propaganda, que contrapõem a mensagem à suposta verdade das intenções dos empresários, a exemplo do ensaio de W. Haug. ${ }^{4}$ Nesse jogo de claro-escuro, poderíamos nos contentar em desvelar a verdade do lançamento da Brahma Chope: uma fraude comercial, uma vez que o produto prometido - chope engarrafado - esbarrava em impossibilidades técnicas insuperáveis. ${ }^{5}$ Mas, essa forma de abordar o assunto seria pouco relevante para a compreensão

Carl H. Miller (1998), Breweries of Cleveland. Cleveland: Schnitzelbank Press, 1998. Wolfgang Haug (1997), Crítica da Estética da Mercadoria. São Paulo: Unesp.

Até o momento de serem engarrafados, não há diferença entre o chope e a cerveja, desde que resultem do mesmo processo de produção, com a mesma proporção de matéria-prima por centímetro cúbico da bebida. Na etapa do envasamento, o chope é acondicionado em barris retornáveis. A cerveja, por sua vez, é acondicionada em garrafas que são submetidas ao processo de pasteurização. Nos padrões tecnológicos da época, pasteurizar significava submeter a cerveja engarrafada a um brusco choque térmico: primeiro em água fervente, depois em água fria. Com esse procedimento, a fermentação do líquido é suspensa e seus componentes orgânicos morrem. A cerveja engarrafada, após ter sido pasteurizada, podia ser conservada por vários meses, enquanto o chope, justamente por não ser submetido ao mesmo processo, devia ser consumido em 72 horas, sob pena de se deteriorar. No entanto, o processo de pasteurização implicava uma elevada perda de garrafas, uma mercadoria escassa e cara naqueles dias.

Veja-se sobre este assunto os trabalhos de: Stanley Baron (1962), Brewed in América. The History of Beer and Ale in the United States, Boston: Little Brown \& Co.;Josimar Melo (2000), A Cerveja, São Paulo: Publifolha; Stephen Snyder (1998), The Beer Companion, London: Quintet Publishing; Memorial da Cia. Antártica ao Conselho Técnico de Economia e Finanças, março de 1938, cx. 100, AB. 
do desenvolvimento da indústria de cerveja no Brasil, e, por isso, logo, a descartamos.

Entendemos que o lançamento da cerveja Brahma Chopp foi, ao mesmo tempo, resultado do declínio das vendas no início da década de 1930 e sintoma de um processo mais profundo de reformulação da imagem da empresa, cuja origem deve ser buscada no ambiente político germanófobo observado na América Latina durante a Primeira Guerra Mundial.

Este ensaio envolve as seguintes partes: na primeira, apresenta-se o perfil dos produtores de cerveja no antigo Distrito Federal ao final dos anos 1920; na segunda, avalia-se o impacto da crise econômica deflagrada no segundo semestre de 1929 sobre a Brahma e, na terceira, examinase a estratégia de lançamento da cerveja Brahma Chopp. Seguem-se as conclusões.

\section{Quem eram os produtores}

Após um longo e bem-sucedido processo de concentração empresarial, é difícil perceber que as grandes cervejarias hoje existentes no mercado brasileiro tiveram origem, em sua maioria, na última década do século XIX. ${ }^{6}$ Observamos hoje no Brasil um mercado produtor de cerveja extremamente concentrado, mas a tendência à concentração nesse setor da indústria já se manifestava nos últimos anos do século XIX. O valor da produção das quinze maiores cervejarias relacionadas no Inquérito Industrial de 1907 correspondia a $67,1 \%$ do total da produção de cerveja apurado. Seis empresas desse grupo haviam investido em tecnologia de refrigeração na segunda metade da década de 1890 , de modo a converter seu sistema de fabricação de alta para baixa fermentação.' Nesse conjunto de produtores já figuravam a Brahma e a

A Cia. Antártica Paulista surgiu, como sociedade anônima, em 1891; já a Brahma foi fundada em 1888, substancialmente expandida a partir de 1896 e convertida em sociedade anônima em 1904.

A partir da aquisição de sistemas de refrigeração, as cervejarias podem fermentar a cerveja sob baixas temperaturas, possibilitando retardar o processo de fermentação e melhor controlar a qualidade final do produto. Como complemento, as cervejarias de baixa fermentação usam levedo de depósito, que produz melhores resultados na fermentação em temperaturas frias. Já as cervejarias de alta fermentação usavam levedo superficial, mais eficiente em temperaturas elevadas, ou ambientais.

No entanto, há vivas controvérsias quanto à qualidade e ao paladar da cerveja produzida desta ou daquela forma, e não há meios que levem a afirmações definitivas 
Antártica Paulista, que operavam em escala industrial, empregando equipamentos de refrigeração c contratando a maior parte dos operários do setor.

No âmbito das cervejas de baixa fermentação, formou-se, no Brasil, o que a literatura econômica denomina de oligopólio diferenciado, que é uma forma de organização produtiva em que uma parcela restrita dos produtores competem entre si, investindo em tecnologia na busca da melhoria da qualidade de seus produtos. ${ }^{8}$ Estabelece-se uma lógica competitiva que se sustenta na diferenciação dos produtos em função de características peculiares. Desse modo, como, no Brasil, as grandes cervejarias de baixa fermentação produziam uma grande variedade de cerveja, foi preciso adotar um conjunto de estratégias para interferir no mercado, garantir a preferência dos consumidores por suas cervejas e impedi-los de migrar para as cervejas de alta fermentação, menos variadas e mais baratas. Nesse ponto, a propaganda teve um papel de destaque na diferenciação dos produtos, com mensagens que enfatizavam aspectos do paladar e as virtudes higiênicas das cervejas industriais, pois era preciso tornar evidentes esses atributos de modo a persuadir os consumidores a incorporar aqueles produtos nas suas escolhas.

O censo de 1920 revelou a existência de 35 estabelecimentos produtores de cerveja no Distrito Federal. Desses, apenas um, certamente a Brahma, empregava mais de 500 operários. Entre os demais estabelecimentos, $51,4 \%$ contratavam entre 10 e 19 operários, uma média de 13 operários por fábrica. Essas muitas pequenas cervejarias empregavam o sistema de alta fermentação, que requeria tecnologia menos avançada e menores investimentos do que os necessários às grandes empresas, como a Brahma e a Hanseática, as maiores do Distrito Federal à época do censo.'

As diferenças no processo produtivo de cervejas de baixa e de alta fermentação residiam não só no método de fabricação como no volume do capital requerido. As cervejas de baixa fermentação, por empregar tecnologia de produção mais sofisticada, exigiam maior investimento

a esse respeito. Cf.Teresa Cristina Novaes Marques (2003), Capital, Cerveja e Consumo de Massa: a trajetória da Brahma, 1888-1933, capítulo I.

Paolo Sylos-Labini (1984), Oligopólio e Progresso Técnico. Rio de Janeiro: Forense Universitária, capítulo II.

BRASIL. Ministério da Agricultura, Indústria e Comércio. Diretoria Geral de Estatística. Recenseamento Geral do Brasil, 1\%/9/1920. Agricultura e Indústrias - Distrito Federal. Rio de Janeiro:Tipografia da Estatística.Vol. II, V parte, pág. 88/89,1924. 
em equipamentos, o que, certamente, implicava maiores ganhos de produtividade em relação às cervejarias de baixa fermentação. Desconsiderando a questão do sabor das cervejas,já que não se dispõe de dados a respeito, é certo que, do ponto de vista do consumidor, a cerveja de baixa fermentação apresentava a desvantagem de ser mais cara. Em compensação, tinha a reputação de ser um produto de melhor qualidade, pois o discurso das grandes cervejarias enfatizava a idéia de que a sua cerveja era uma bebida industrial, cuja fabricação era fundamentada em pesquisas científicas desenvolvidas na Europa, ao contrário das demais bebidas, produzidas sem rigor científico. Ressalte-se que, para os consumidores brasileiros do início do século XX, esse discurso vinha ao encontro de uma exaltação à modernidade e à civilização industrial, o que favoreceu a difusão do consumo dessa bebida entre nós.

Naquela época, as cervejarias de baixa fermentação classificavam seus produtos em três tipos, levando em conta um critério simultaneamente técnico e contábil. ${ }^{10} \mathrm{O}$ primeiro tipo correspondia às cervejas de maior teor de malte importado; o segundo, às de teor médio de malte importado e, por fim, as cervejas mais fracas, de menor custo de produção e preços menores, competiam no mercado com as cervejas de alta fermentação. Antes da crise dos anos trinta, o forte das grandes cervejarias estava nas vendas de cerveja de alto custo, cujos resultados compensavam as vendas menores de produtos populares.

A competição no mercado de cerveja seguia, portanto, padrões distintos conforme o tipo de cerveja. Entre as cervejarias de baixa e de alta fermentação imperava a rivalidade no plano das cervejas de consumo popular, e as cervejarias de baixa fermentação disputavam entre si o mercado das cervejas de primeiro e de segundo tipos. No Distrito Federal, onde havia um conjunto importante de pequenas cervejarias, a disputa pelo consumidor de baixa renda era acirrada.

O mercado produtor do Distrito Federal, revelado pelo censo de 1920 , caracterizava-se por intensa concorrência no segmento do consumo popular. Essa característica só tendeu a se aprofundar ao longo da década. A despeito das várias tentativas das cervejarias de baixa fermentação para impor custos mais elevados de operação às fábricas de alta fermentação, como pressionar o Congresso para elevar a carga fiscal sobre o produto concorrente e negociações de bastidores para aumentar

\footnotetext{
"Em verdade, os relatórios de produção da Brahma empregam o termo qualidade para descrever os três tipos de cerveja produzidas pela empresa.
} 
o preço do gelo, a presença das cervejarias de alta fermentação não se reduziu. ${ }^{11}$

Vejamos de que forma se comportavam as vendas de cerveja de alta e baixa fermentação, ao final da década, no mercado brasileiro. Juntos, Distrito Federal, São Paulo, Minas Gerais, Santa Catarina, Rio Grande do Sul e Rio de Janeiro eram responsáveis, entre 1925 e 1929, por 94\% do valor da produção nacional de cerveja. ${ }^{12}$

Tabela 1. Relação entre valor da produção de cervejas de alta fermentação e o valor da produção de baixa fermentação(\%)

\begin{tabular}{lrrrrr}
\hline Estados & 1925 & 1926 & 1927 & 1928 & 1929 \\
\hline Distrito Federal & 36,85 & 52,78 & 53,03 & 51,80 & $60,1.8$ \\
São Paulo & 3,93 & 3,30 & 38,93 & 17,74 & 15,24 \\
Minas Gerais & 6,87 & 85,39 & 24,48 & 18,77 & 19,62 \\
Rio Grande do Sul & 3,82 & 3,56 & nd & 2,10 & 2,39 \\
Santa Catarina & 627,87 & 110,95 & 212,55 & 148,32 & 105,37 \\
Rio de Janeiro & 31,63 & 47,45 & 65,15 & 147,46 & 150,58 \\
\hline
\end{tabular}

Fonte: Estatística da Produção Industrial, pág. 119.

Os dados da Tabela 1 mostram o crescimento da produção de cervejas de alta fermentação em relação às de baixa fermentação no Distrito Federal. Dados do Imposto de Consumo confirmam que, no final dos anos vinte, mesmo após terem sido baixadas importantes restrições legais ao comércio de cerveja de alta fermentação, esse tipo de cervejaria continuou ocupando um lugar relevante no comércio de cervejas da Capital Federal, a ponto de a Brahma desistir de confrontar as cervejarias de alta fermentação e passar a adotar estratégias para ganhar posições no mercado das cervejas dessa categoria. ${ }^{13}$ Sua principal medida foi o

\footnotetext{
Os fabricantes de cerveja de alta fermentação não eram auto-suficientes na produção de gelo, de que precisavam tanto para a produção quanto para o fornecimento aos salões contíguos à fabrica onde a cerveja era vendida aos consumidores.

Optou-se pelo valor da produção, em vez de considerar a quantidade produzida, porque os dados publicados na Estatística da Produção Industrial só estão desagregados por Estado, na tabela referente a valores. Também a partir dela, é possível discriminar entre os valores da produção das cervejarias de alta das de baixa fermentação. BRASIL. Ministério do Trabalho, Indústria e Comércio, Departamento Nacional de Estatística, Estatística da Produção Industrial, 1915-1929. Rio de Janeiro: Tipografia do Departamento Nacional de Estatística, 1933, pág. 119.

O Governo Federal fez inserir um artigo na lei orçamentária elaborada em 1922 que proibia as fábricas de cerveja de alta fermentação de vender seus produtos em espaço conjugado às instalações da fábrica. A medida tinha o propósito de evitar a
} 
relançamento da marca ABC em novembro de $1927 .{ }^{14}$ No que tange à evolução da produção das cervejas de baixa e alta fermentação, os dados da Tabela 1 mostram o contraste acentuado entre o Distrito Federal e São Paulo na segunda metade dos anos vinte. Nesse último Estado, ao contrário do que ocorria no Distrito Federal, a produção de baixa fermentação dominava o mercado com folga.

Ainda sobre a competição entre cervejas de alta e de baixa fermentação nos Estados produtores, o leitor há de se conformar com as informações apresentadas, que se estendem apenas até o ano de 1929. Os dados disponíveis não nos permitem mensurar a dimensão do impacto da crise econômica de 1930/1933 sobre o mercado produtor de cerveja de alta fermentação, especialmente no Distrito Federal. ${ }^{15}$

A despeito da evidente concorrência acirrada no mercado local, as vendas da Cervejaria Brahma responderam, entre 1927 e 1929, em média, por $51,3 \%$ do valor da produção industrial de bebidas sujeitas ao Imposto de Consumo no Distrito Federal. ${ }^{16}$ A posição relativa

sonegação de impostos e, ao desrespeitá-la, a cervejaria estava sujeita a perder o registro fiscal.Teresa Cristina de Novaes Marques (2003), Capital, Cerveja e Consumo de Massa: a trajetória da Brahma, 1888-1933, cap. III.

${ }^{14}$ A cerveja ABC, fabricada sob o sistema de alta fermentação e lançada em 1905, teve sua produção descontinuada antes da Primeira Guerra Mundial e foi relançada ao final de 1927. No relatório da Diretoria ao Conselho Fiscal referente ao mês de novembro de 1927, consta a primeira menção às vendas de cerveja A BC. Felizmente, as vendas dessa marca estão classificadas em separado das demais categorias de cerveja, o que facilita a recomposição da trajetória das vendas desse produto. A ABC era oferecida na variedade escura, doce, e branca, amarga. Apontamentos desde 1894; cx. 95 , port.,/4B.

A série de valores da produção de cerveja de alta e de baixa fermentação mostrada no Anuário Estatístico do Brasil de 1939/40 discrimina as duas categorias de cerveja apenas no período compreendido entre 1915 e 1929, com valores relativos a todo o País - isto é, não discriminando a arrecadação do Imposto de Consumo por Estado da Federação. BRASIL, IBGE/Conselho Nacional de Estatística, Anuário Estatístico do Brasil, 1939/40,píg. 33.

16 Se considerarmos os produtos sujeitos ao Imposto de Consumo nos anos de 1919, 1922,1925,1928 e 1929, as cervejas representaram, em média, 63,4\% da quantidade de bebidas sujeitas a ele. As demais bebidas mencionadas na estatística do Imposto de Consumo eram: refrescos gasosos, vinho, bitter, fernet, vermute, conhaque, laranjinha, genebra, uísque,rum e vinhos artificiais. Note-se a ausência da aguardente de cana nessa relação, embora o produto estivesse sujeito ao imposto. BRASIL. Ministério do Trabalho, Indústria e Comércio, Departamento Nacional de Estatística, Estatística da Produção Industrial, 1915-1929. Rio de Janeiro,Tip. do Dep. Nacional de Estatística, 1933, pág. XII. 
das vendas da Brahma no Distrito Federal é mostrada a seguir na Tabela 2 .

Tabela 2. Cerveja: valor das vendas da Brahma e valor declarado da produção de cerveja no Distrito Federal para fins de pagamento de Imposto de Consumo

\begin{tabular}{lccc}
\hline Anos & $\begin{array}{l}\text { Valor total da produção de cerveja } \\
\text { de alta e baixa fermentação }\end{array}$ & Vendas da Brahma & $\begin{array}{c}\text { Brahma s/valor } \\
\text { total }(\%)\end{array}$ \\
\hline 1927 & $87: 279: 147 \$$ & $48: 976: 595 \$$ & 56,11 \\
1928 & $97: 558: 909 \$$ & $50: 065: 677 \$$ & 51,32 \\
1929 & $90: 476: 107 \$$ & $42: 048: 296 \$$ & 46,47 \\
\hline
\end{tabular}

Fontes: vendas da Brahma, reconstituídas a partir dos relatórios da Diretoria ao Conselho Fiscal, mês a mês [AB]; Estatística da Produção Industrial, pág. 119.

\section{A crise de 1929-1933}

Os efeitos da depressão econômica, deflagrada no final do ano de 1929, não foram sentidos da mesma forma em todos os setores da economia. O impacto foi mais intenso no setor cafeeiro, cuja renda declinou e não mais se recuperou no restante da década, enquanto a produção industrial sofreu menos o impacto da crise e, em meados da década de 1930 já mostrava sinais de recuperação do seu nível de atividade. ${ }^{17}$ Mas, também, essa recuperação não se deu com a mesma intensidade nem de forma sincrônica em todos os setores. Os produtores de bens de consumo popular foram os mais afetados pela conjuntura recessiva. Em particular aqueles que produziam bens cuja elasticidade-renda era mais elevada, como era o caso da cerveja. ${ }^{18}$ No entanto, as diferentes variedades de cerveja — as já mencionadas cervejas de primeiro, segundo e terceiro tipo - apresentavam elasticidades-renda distintas, donde se conclui que a crise econômica teve impactos diferenciados entre elas.

Nos anos de 1929-1932, o nível de produção na indústria de bebidas, no qual predominavam as cervejarias, não declinou de modo tão

Ao avaliar o impacto da política de compra do café, a partir de 1931, na manutenção da renda real do setor cafeeiro, Edmar Bacha mostra que a parcela do café no PIB brasileiro caiu, de fato, ao longo da década de 1930.E. Bacha (1992), Política brasileira do café, em Marcelino Martins \& E.Johnston, 150 anos de Café, São Paulo:Salamandra Editorial.

" Veja-se a este respeíto:Annibal V. Villela e Wilson Suzigan (1973), Política do Governo e Crescimento da Economia Brasileira, 1889-1945, Rio de Janeiro: IPEA/INPES, p. $191-199$. 
acentuado quanto nas demais indústrias de bens de consumo de massa." Assim, durante aqueles anos, as cervejarias conseguiram manter-se entre as principais indústrias do País no que se refere ao volume de impostos pagos e ao número de operários empregados. ${ }^{20}$

Do ponto de vista dos custos de produção, a crise cambial que teve início nos primeiros meses de 1930 afetou significativamente o setor cervejeiro, dada a dependência desse setor de matérias-primas importadas. A fim de contornar os problemas gerados pela depreciação do câmbio, pressões por tarifas alfandegárias protecionistas para cevada e malte já não bastavam. Cabe observar, entretanto, que o impacto da depreciação cambial sobre os custos de produção foi amenizado pela queda dos preços internacionais de produtos agrícolas — inclusive os da cevada que se observou no período. ${ }^{21}$ Vejamos o comportamento dos preços internacionais da cevada, a principal matéria-prima importada pelas cervejarias brasileiras.

Desconhecendo-se o preço por quilo desse cereal na praça comercial de Nova York, onde a Brahma vinha comprando matéria-prima desde o início da Primeira Guerra Mundial, tomamos como medida aproximada do valor da cevada os preços pagos ao produtor em um grande Estado agrícola norte-americano. Esses preços são mostrados a seguir na Tabela 3 .

Admitindo que os preços pagos internamente aos produtores norteamericanos acompanhavam os preços internacionais da cevada, podemos usar os dados dessa tabela para examinar o impacto conjunto de variações nos preços internacionais e no câmbio sobre os preços desse produto no Brasil. Os dados da Tabela 3 deixam claro que os produtores brasileiros de cerveja não puderam se beneficiar integralmente da queda significativa

\footnotetext{
19 A taxa anual de crescimento da produção industrial dos setores de vestuário e calçados, bebidas e fumo declinou, em média, 8,7\%, entre 1929 e 1932. No período seguinte, de 1933 a 1939, esses três setores elevaram a sua taxa de crescimento à média de $7,8 \%$ ao ano, mostrando capacidade de recuperação. No entanto, seu crescimento foi bastante inferior ao conjunto do setor industrial, cujo incremento nesses anos esteve na média de 11,2\%, ao ano.Villela e Suzigan (1975), Política do Governo e Crescimento da Economia, tabelas VI.7 e VI.8, págs. 193-194.

${ }^{20}$ No ano de 1929, as bebidas representaram 32\% do total arrecadado pelo Imposto de Consumo. BRASIL. Ministério do Trabalho, Indústria e Comércio, Departamento Nacional de Estatística, Estatística da Produção Industrial, 1915-1929. Rio de Janeiro: Tip. do Dep. Nacional de Estatística, 1933, pág. 7, tab. 2.

${ }^{21}$ Charles Kindleberger (1993) A Financial History of Western Europe. New York: Oxford University Press, pág. 371 .
} 
dos preços da cevada no comércio internacional nos anos 1929-1932. Na verdade, a redução do preço da cevada foi substancial: o preço de um bushel, que em 1929 era de US\$ 0,65 caiu para US\$ 0,23 em 1932, uma redução de aproximadamente $65 \%$. Entretanto, como o valor do dólar em mil-réis aumentou cerca de $137 \%$ no mesmo período, os preços em mil-réis das importações se elevaram. Com efeito, o preço internacional do bushel de cevada em mil-réis passou de $5 \$ 45$ em 1929 para $9 \$ 89$ em 1932, um aumento de $81 \%$. A partir de 1933, entretanto, a recuperação dos preços da cevada no comércio internacional foi a maior responsável pela evolução dos preços internos desse cereal,já que a taxa cambial permaneceu relativamente estável de 1935 em diante.

Tabela 3. Evolução dos preços médios anuais da cevada em dólares e em mil-réis, 1928-1937

\begin{tabular}{|c|c|c|c|c|c|c|c|}
\hline \multirow[t]{2}{*}{ Anos } & \multicolumn{2}{|c|}{$\begin{array}{l}\text { (A) Preços médios anuais } \\
\text { pagos aos produtores norte- } \\
\text { americanos (dólares por } \\
\text { bushel*) }\end{array}$} & \multicolumn{2}{|c|}{$\begin{array}{l}\text { (B) Taxas de câmbio } \\
\text { (mil-réis por dólar) }\end{array}$} & \multicolumn{3}{|c|}{$\begin{array}{l}\text { Preços médios anuais pagos } \\
\text { convertidos para } \\
\text { mil-réis por bushel }\end{array}$} \\
\hline & $\begin{array}{l}\text { valores } \\
\text { absolutos }\end{array}$ & $\begin{array}{l}\text { variações } \\
\text { anuais (\%) }\end{array}$ & $\begin{array}{l}\text { valores } \\
\text { absolutos }\end{array}$ & $\begin{array}{l}\text { variações } \\
\text { anuais }(\%)\end{array}$ & $\begin{array}{l}\text { valores } \\
\text { absolutos }\end{array}$ & $\begin{array}{l}\text { variaç } \\
\text { anuais }\end{array}$ & $\begin{array}{l}\text { çoes } \\
\text { s }(\%)\end{array}$ \\
\hline 1928 & 0,54 & & 8,37 & 0 & $4 \$ 52$ & & - \\
\hline 1929 & 0,65 & 20 & 8,38 & 0 & $5 \$ 45$ & & 21 \\
\hline 1930 & 0,40 & (-) 38 & 9,05 & 8 & $3 \$ 62$ & & 44 \\
\hline 1931 & 0,40 & 0 & 15,77 & 74 & $6 \$ 31$ & & 74 \\
\hline 1932 & 0,23 & (-) 42 & 19,83 & 26 & $9 \$ 89$ & & 57 \\
\hline 1933 & 0,36 & 57 & 18,49 & (-) 7 & $6 \$ 66$ & & 32 \\
\hline 1934 & 0,61 & 69 & 19,48 & 5 & $11 \$ 88$ & & 78 \\
\hline 1935 & 0,50 & (-) 18 & 26,86 & 38 & $13 \$ 43$ & & 13 \\
\hline 1936 & 0,79 & 58 & 26,67 & $(-) \quad 1$ & $21 \$ 07$ & & 57 \\
\hline 1937 & 0,51 & $(-) 35$ & 25,32 & $(-) 5$ & $12 S 91$ & $(-)$ & 39 \\
\hline
\end{tabular}

* Bushel: medida de capacidade, equivalente a 35 litros.

Fontes: (A) National Agricultural Statistic Service [www.nass.usda.gov]

(B) Câmbio:Tabela 1.10, Apêndice Estatístico [Martins \& Johnston (1992), 150 Anos de Café].

Cabe lembrar que os efeitos de uma depreciação do câmbio sobre os custos de produção, na ausência de reduções compensatórias nos preços internacionais, não se resumem a aumentos de preços das matérias-primas importadas. Os aumentos do preço em moeda estrangeira também encarecem as importações de máquinas e equipamentos e podem vir a desestimular os investimentos. Entretanto, em certos casos, a depreciação cambial pode beneficiar os produtores locais. Reduções no valor externo da moeda nacional aumentam os preços internos dos produtos similares importados, criando espaço para aumentos dos preços e, conseqüentemente, dos lucros destes produtores. No caso da cerveja 
brasileira, entretanto, não era de se esperar que ela tivesse se beneficiado, na época, de maiores margens de lucros por causa da depreciação cambial. Isto porque o produto estrangeiro similarjá não era um sério concorrente à cerveja nacional desde antes da Primeira Guerra Mundial. No que tange aos efeitos adversos da depreciação cambial sobre as importações de máquinas e equipamentos, cumpre observar que a expansão dos seus investimentos nos anos vinte dotara a Brahma de uma capacidade de produção suficiente para atender suas necessidades na década seguinte. ${ }^{22} \mathrm{O}$ setor cervejeiro constituía, portanto, naquela época, uma parcela madura da indústria nacional, capaz de responder prontamente a aumentos da demanda e já suficientemente articulado com as elites políticas nacionais para garantir seus interesses quando fosse necessário, principalmente na discussão das políticas tarifária e fiscal.

$\mathrm{Na}$ verdade, se não fosse o investimento realizado no período anterior à grande crise, a Brahma não teria podido responder à recuperação da demanda que se manifestou a partir do verão de 1935, como mostram os Gráficos 1 e 4 - o primeiro relativo às receitas de vendas de cerveja, e o segundo, às quantidades vendidas. De fato, dadas as dificuldades criadas às importações pela depreciação do valor externo da moeda nacional na primeira metade dos anos trinta, pode-se supor que o crescimento da produção da Brahma para atender ao reaquecimento da demanda interna só tenha sido possível graças à utilização de sua capacidade ociosa. Com efeito, como mostram os dados da tabela anterior, o valor médio anual do dólar em mil-réis triplicou entre os períodos de 1928-1929 e 1935-1937.

Mas, vejamos, agora, como evoluiu a competição no mercado de cerveja no País. Quando surgiram as grandes cervejarias no Brasil, na década de 1890, o produto importado ainda era um concorrente importante. Esse obstáculo foi superado por barreiras alfandegárias, ganhos

\footnotetext{
Ao longo dos anos vinte, a empresa destinou a maior parcela de seus investimentos a máquinas novas no setor de engarrafamento, onde eram elevadas as perdas ocorridas durante o processo industrial, especialmente de garrafas. Se considerarmos o total do dispêndio com máquinas novas, entre 1922 e 1934, encontramos o valor expressivo de Rs. 3:343:653\$000. Desse total, 63\% dos recursos da Brahma foram empregados no setor de engarrafamento. Balanço Geral da Cia. Brahma, 31/12/1934; cx. 30, port., AB.

A demanda por sistemas de engarrafamento de maior eficiência foi crescente em todo o mundo. Os fabricantes de equipamentos, com destaque para a empresa norte-americana Crown Cork, procuraram responder a ela com sucessivas inovações tecnológicas.
} 
de produtividade e pela boa qualidade do produto nacional. Ao final dos anos vinte, os adversários das grandes cervejarias eram os produtores domésticos estabelecidos, por vezes, no outro lado da rua da fábrica: as muitas pequenas cervejarias de alta fermentação e os produtores de outras bebidas alcoólicas, como a aguardente.

A aguardente - parati ou cachaça - sempre foi um importante substituto da cerveja para o consumidor de baixa renda, como revela a preocupação dos ativistas políticos do movimento pró-temperança, que pressionavam o Governo e os parlamentares a adotar medidas para restringir a produção e o consumo de aguardente no País. ${ }^{23} \mathrm{Um}$ exemplo dessa mobilização política anti-álcool foi a visita de uma comissão de médicos e ativistas pró-temperança ao Presidente da República, no final de 1928. Esse grupo levou ao Presidente a proposta da criação de uma sobretaxa sobre o litro de aguardente. Esse episódio, um entre muitos atos da campanha pró-temperança, que se espalhou pelo País nos anos 1920, repercutiu na imprensa carioca, como se constata nos comentários do jornal O Imparcial: ${ }^{24}$

Demonstram mais as estatísticas: $82 \%$ do álcool ingerido o é sob a forma de aguardente, bebida de baixo custo e de elevado teor etílico (mais de 50\%). O alcoolismo brasileiro é, pois, essencialmente, aguardentismo das classes pobres.

Embora ojornal faça menção a números extraordinários de consumo de aguardente, há que se ver com cautela a porcentagem mencionada. Tratava-se mais de um ingrediente de discurso político do que de um indicador econômico confiável. Com efeito, mesmo hoje em dia, temos dificuldades para mensurar a evolução do consumo da cachaça nas pri-

Entre 1917 e 1930, vários projetos de lei foram apresentados no Congresso prevendo medidas para limitar o consumo de bebidas alcoólicas no País. Quase sempre os projetos propunham sobretaxas sobre bebidas alcoólicas, especialmente sobre a aguardente de cana e a cerveja de alta fermentação. Entretanto, nenhum deles chegou a se tornar lei, pois os produtores de álcool e aguardente cerravam fileiras contra propostas que atingissem seus interesses. Há razões para pensar que também as cervejarias de baixa fermentação pressionavam o Congresso para rejeitar projetos pró-temperança. Cf.Teresa Cristina de Novaes Marques (2003), Capital, Cerveja $e$ Consumo de Massa, capítulo V.

Notícia sobre a visita de uma comissão composta por membros da Liga Brasileira de Higiene Mental, da Sociedade de Medicina e Cirurgia e da Academia Nacional de Medicina ao Presidente da República, O Imparcial, 25/12/1928. 
meiras décadas do século XX, já que as estatísticas disponíveis não são muito confiáveis.

Em 1922, por exemplo, a produção nacional de cerveja de alta fermentação, estimada pela arrecadação do Imposto de Consumo, foi de 272.059 hectolitros e a produção de aguardente, de 1.050 .784 hectolitros. ${ }^{25}$ Esses números, embora expressivos, parecem subestimar a participação da aguardente no mercado produtor de bebidas. De fato, em 1920, havia 308 estabelecimentos industriais formalmente constituídos para produzir álcool e aguardente, ao passo que existiam 64 mil estabelecimentos rurais - fazendas e sítios - identificados como produtores de aguardente. ${ }^{26}$ Entretanto, se os próprios organizadores do Censo de 1920 admitiram não ter investigado as propriedades rurais produtoras de aguardente situadas na Baixada Fluminense, a pouca distância do centro da capital do País, o que dizer da fiscalização da arrecadação do Imposto de Consumo nessas localidades $?^{27}$ Certamente, grande parte da produção doméstica de aguardente estava fora do alcance desses fiscais. Mesmo no Estado de São Paulo, o segundo maior produtor nacional de aguardente depois de Pernambuco, a produção de cerveja declarada ao imposto de consumo foi cerca de 2,5 vezes maior do que a produção de aguardente, entre 1925 e 1929, o que levanta suspeitas sobre a capacidade do Estado de arrecadar impostos sobre a aguardente. ${ }^{28}$

Além disso, quanto a uma comparação entre os níveis de produção

BRASIL, IBGE/Conselho Nacional de Estatística, Armário Estatístico do Brasil, 1939/ 1940, pág. 33 .

O número de produtores de aguardente é informado pelo Censo de 1920 na versão publicada em 1927. BRASIL, Ministério da Agricultura, Indústria e Comércio. Diretoria Geral de Estatística. Recenseamento Geral do Brasil, 1\%/9/1920. Agricultura e Indústrias, vol.V, 1ª parte, pág.VI, 1927. Em 1920, a produção nacional de álcool declarada ao imposto de consumo correspondia a $27,2 \%$ do valor da produção de aguardente. BRASIL, IBGE/Conselho Nacional de Estatística, Anuário Estatístico do Brasil, 1939/40, pág. 33.

No capítulo introdutório do Censo de 1920, os organizadores admitiram não ter recenseado, entre outros estabelecimentos, destilarias vinculadas a estabelecimentos rurais no Distrito Federal. Recenseamento Geral do Brasil, 1\%/9/1920, Agricultura e Indústrias - Distrito Federal, vol. II, $1^{\text {a }}$ parte, 1924.

- Consideramos a quantidade produzida declarada pelas fábricas aos fiscais do Imposto de Consumo entre 1925 e 1929. No Estado de São Paulo, onde se sabe que havia poucas cervejarias de baixa fermentação contra muitos produtores de aguardente, era de se esperar que a produção de aguardente de cana superasse a de cerveja, o que não acontecia. Ressalve-se que a estatística do Imposto de Consumo somava à aguardente de cana, bebidas alcoólicas derivadas de mandioca e do álcool de uva. 
da cerveja e da aguardente, há que se considerar a tecnologia adotada. Ao contrário da cerveja, a produção de aguardente de cana não implicava elevados gastos de investimento com instalações e equipamentos e não requeria matérias primas importadas. Além de custos de produção relativamente mais baixos, outro fator aumentava a competitividade da aguardente no mercado consumidor de bebidas alcoólicas: sua distribuição comercial nos mercados urbanos se fazia por canais informais, facilitando a sonegação de impostos. Com menores custos, os preços da aguardente eram bastante menores que os da cerveja, daí a preferência popular pela cachaça.

A crise veio acirrar a competição pela demanda do consumidor popular de bebidas alcoólicas. No início dos anos trinta, mesmo os que se mantiveram fiéis ao consumo de cerveja tenderam a optar por marcas mais baratas, como nitidamente se observa na evolução das vendas da Brahma entre 1927 e 1937, mostrada no Gráfico 1.0 declínio das vendas para o Interior - ou exportações, como os relatórios da Diretoria de nominavam as vendas a mercados onde a cerveja chegava por via férrea ou por cabotagem - , a partir do primeiro trimestre de 1930, pode ser visto no Gráfico 3. ${ }^{29}$ Face à conjuntura de crise, a Brahma precisou reformular a sua estratégia de vendas no perímetro da cidade do Rio de Janeiro para compensar sua perda de mercados no Interior. O consumidor carioca era disputado pelas muitas cervejarias de alta fermentação locais e por cervejarias de baixa fermentação - como a Antártica Paulista, a Hanseática, a Polônia (essas duas últimas eram empresas cariocas) e a Ritter, do Rio Grande do Sul. Isso, para mencionar apenas as fábricas mais importantes, que buscavam vender seus produtos no Distrito Federal.

BRASIL. Ministério do Trabalho, Indústria e Comércio, Departamento Nacional de Estatística, Estatística da Produção Industrial, 1915-1929. Rio de Janeiro, Tip. do Dep. Nacional de Estatística, 1933, págs. 119 e 132.

${ }^{29}$ Ao examinarmos uma amostra do saldo de vendas a fregueses do Interior em dezembro de 1931, constante da Lista de fregueses do interior (cx.08,port., Acervo Brahma), observamos que as remessas de mercadorias a localidades situadas no Estado de Minas Gerais representaram 67,2\% do conjunto estudado.As remessas para o Estado do Rio de Janeiro somavam 17,2\%, a São Paulo, 5,18\%, ao Espírito Santo, 7\%, e os demais estados participavam com 3,25\% do total. Levantamos as vendas para 234 municípios, com o que chegamos ao total de Rs 2.116:639\$094, sendo que a soma total das vendas interioranas e costeiras, em 1931, atingiu Rs 11.997:338\$000.A identificação do estado de origem da localidade, foi baseada em registros do IBGE. BRASIL, IBGE, Cadastro de Cidades e Vilas do Brasil, 1996; Divisão territorial do Brasil, 1945 . 
As cervejas mais caras, as do primeiro tipo, predominavam nas vendas para o Interior. Nas vendas locais, as cervejas de menor preço eram as preferidas, ocupando o chope um lugar estável, com oscilações sazonais de venda, como mostra o Gráfico 3. Contudo, as vendas de exportação respondiam por uma parcela muito expressiva dos resultados da Brahma no período examinado, janeiro de 1927 a junho de 1937. Há que se considerar, entretanto, que as vendas das cervejas do primeiro tipo que predominavam nas vendas de exportação - eram responsáveis pela maior fatia das receitas de venda da Brahma. Assim, como era de se esperar, as alterações nos mercados do Interior afetaram fortemente os resultados da cervejaria, como indicam os Gráficos 1 e 2 .

No entanto, os problemas das cervejarias não se limitaram à redução das vendas para o Interior. Muitas fronteiras no mercado de cerveja se diluíram durante os anos de crise, a começar pela fronteira entre os grandes produtores - as cervejarias de baixa fermentação, que dispunham de ganhos de eficiência produtiva em função da tecnologia que adotavam - e os pequenos produtores, as cervejarias de alta fermentação. O avanço das cervejas populares foi possível porque o mercado consumidor passou a preferir as cervejas mais baratas e de menor qualidade. As grandes cervejarias, antes da crise, compensavam a ausência de barreira tecnológica à entrada no mercado de cervejas populares com o domínio do mercado das cervejas mais caras. Com a crise, todos os produtores se moveram para ocupar o mesmo espaço do mercado - o das cervejas populares. Em conseqüência, a vantagem competitiva da Brahma e de suas congêneres tendeu a enfraquecer-se, como admitiu a Diretoria ao Conselho Fiscal da empresa, em novembro de $1930 .^{30}$

As nossas vendas durante os primeiros quatro meses do corrente ano social importaram em 47.048 hectolitros, com receita total de Rs. 8.854:183\$000, contra 71.559 hectolitros, com receita total de Rs. 15.011:782\$000 em igual época do ano passado.

Essa enorme diminuição de negócios, devida aos motivos que estão no conhecimento de todos, não importa em perda de freguesia ou de terreno conquistado, mas sim é proveniente do retrocesso impressionante nas vendas de cerveja de baixa fermentação em geral no país, contra a concorrência cada vez mais sensível das cervejas baratas, cujas vendas continuam a aumentar constantemente.

\footnotetext{
${ }^{30}$ Relatório da Diretoria ao Conselho Fiscal, 10/11/1930, cx. 93,port. Acervo Brahma,
} 
Durante as primeiras décadas do século $\mathrm{XX}$, as grandes cervejarias buscaram pactuar os preços de cervejas mais caras - as de primeiro e segundo tipos - em níveis suficientes para garantir grandes margens de lucros. Entretanto, no início da década de 1930, a retração geral da demanda provocada por uma queda da renda impediu que essa estratégia de aumento combinado de preços fosse mantida. A saída encontrada foi o lançamento de novos produtos, como a Brahma Chopp.

Gráfico 1. Receitas de venda por tipo de cerveja,jan./1927 ajun./1937 (valores em mil-réis)

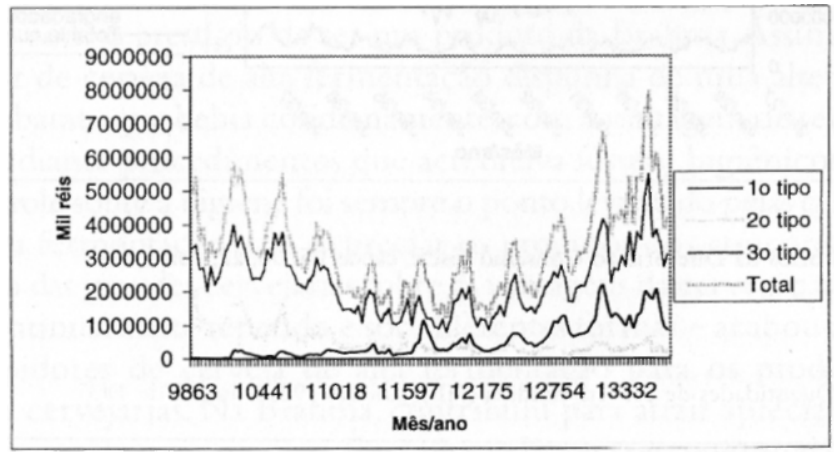

Fontes: relatórios da Diretoria ao Conselho Fiscal, caixas 05, 06, 22, port., $A B$.

Obs.: as cervejas de $1^{\circ}$ tipo incluem a Brahma Chopp, o chope e as cervejas mais caras, vendidas em garrafas; as de $2^{\circ}$ tipo incluem a marca Fidalga, entre outras similares; as de $3^{\circ}$ tipo incluem as vendas das cervejas Cavaleira e ABC.

Gráfico 2.Vendas ao Interior (exportação) por tipo de cerveja (jan./27 a mar./32; valores em milréis)

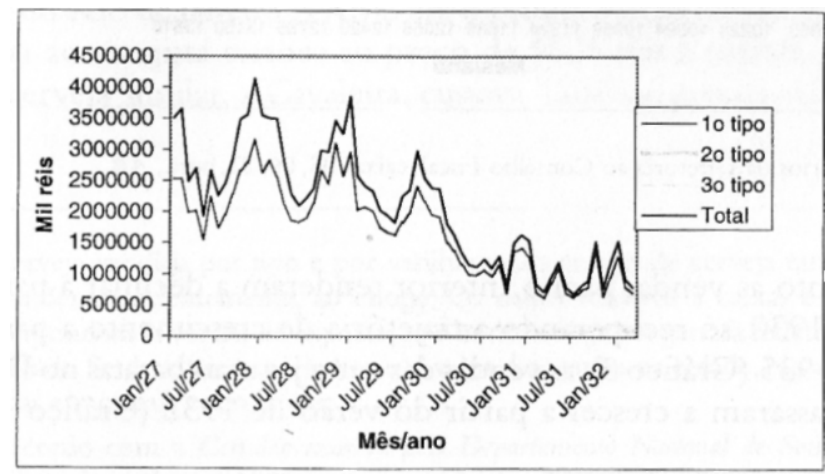

Fontes: relatórios da Diretoria ao Conselho Fiscal, caixas 05, 06, 22, port., $A B$. 
Gráfico 3 Evolução das vendas de cerveja de $1^{\circ}$ tipo,jan./1927 a jun./1937 (por vasilhame; valores em mil-réis)

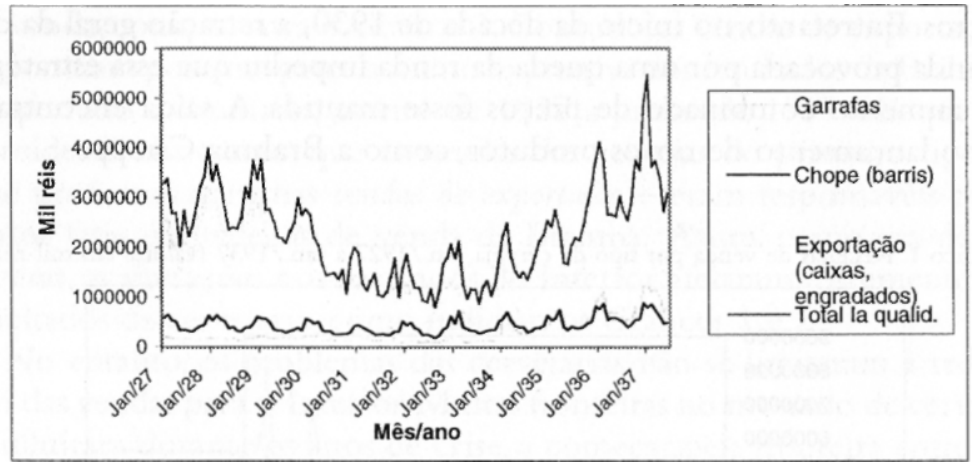

Fontes: relatórios da Diretoria ao Conselho Fiscal, caixas 05, 06, 22, port., $A B$.

Gráfico 4. Quantidades de cerveja vendida (HI), janeiro 1927 a junho de 1937

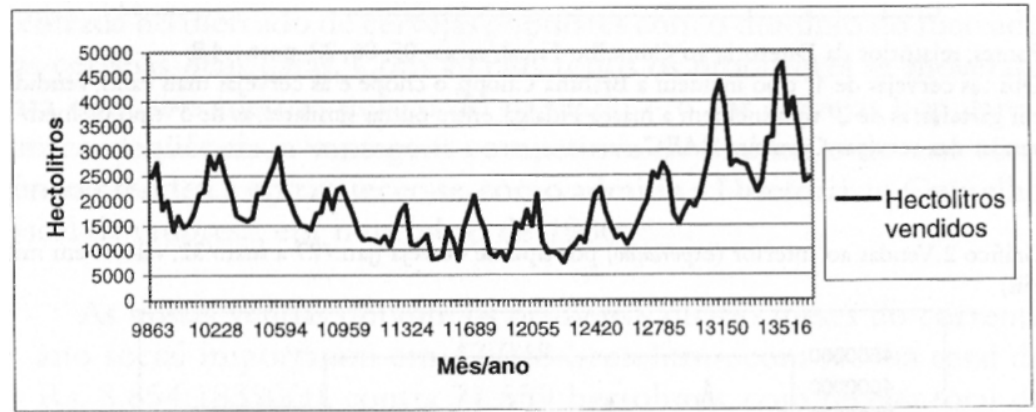

Fontes: relatórios da Diretoria ao Conselho Fiscal, caixas 05, 06, 22, port., $A B$.

Enquanto as vendas para o Interior tenderam a declinar a partir do verão de 1930, só recuperando a trajetória de crescimento a partir do verão de 1935 (Gráfico 3), as vendas das cervejas mais baratas no Distrito Federal passaram a crescer a partir do verão de 1932 (Gráfico 1). ${ }^{31}$ A

"Os relatórios da Diretoria ao Conselho Fiscal discriminam o valor e a quantidade 
própria Brahma contribuiu para esse maior crescimento da produção de cervejas mais baratas. Ao final de 1927, a empresa recolocou no mercado a marca ABC, cuja produção havia sido suspensa durante a Primeira Guerra. E, ao que parece, a ABC atraiu consumidores de cerveja de segundo tipo, como, por exemplo, os consumidores da Fidalga, marca essa que, praticamente, desapareceu do mercado. ${ }^{32}$

A ABC era produzida pelo sistema de alta fermentação e estava sujeita, portanto, ao menor valor do imposto de consumo que incidia sobre esse tipo de cerveja. No entanto, diferentemente dos produtos das pequenas fábricas, a $\mathrm{ABC}$ era submetida ao processo de pasteurização e contava com o prestígio de ser um produto da Brahma. Assim, o consumidor de cerveja de alta fermentação dispunha de uma alternativa à cerveja barata que bebia cotidianamente, com a vantagem de ser produzida mediante procedimentos que acreditava fossem higiênicos. A falta de controle sobre a higiene foi sempre o ponto levantado pelas cervejarias de baixa fermentação para depreciar os produtos dos concorrentes. O discurso das grandes cervejarias sobre as vantagens da cerveja pasteurizada - continuamente repetido e sob diferentes formas - acabou atraindo consumidores de cerveja de alta fermentação para os produtos das grandes cervejarias. Na Brahma, contribuiu para atrair apreciadores de suas cervejas de menor preço. É o que explica o crescimento das vendas de terceiro tipo a partir de 1932 em detrimento das vendas de cerveja de segundo tipo, como mostra o Gráfico 1. A ABC foi capaz inclusive de atrair consumidores de cerveja de segundo tipo da própria Brahma.

Como a ABC era muito pouco vendida no Interior, podemos considerar o desempenho das vendas dessa modalidade de cerveja como um dos principais indicadores da competição no mercado popular da cidade do Rio de Janeiro. A ABC era o produto mais barato da Brahma: chegava ao varejista carioca ao preço de $\$ 625$ réis a garrafa, enquanto outra cerveja similar, a Cavaleira, custava $1 \$ 083$ a garrafa. Uma marca

de cerveja vendida por tipo e por vasilhame. As vendas de cerveja em barris correspondem, evidentemente, ao chope. Os dados relativos a caixas e engradados correspondem às vendas de exportação e os de cerveja em garrafa refletem as vendas na cidade. Se desejássemos conhecer o valor das vendas na cidade, bastaria somar as vendas em garrafa e em barris.

${ }^{32}$ De acordo com a Certidão exarada pelo Departamento Nacional de Saúde Pública, a ABC foi lançada em 1905 como cerveja de alta fermentação. Caixa 110, port., Acervo Brahma. 
de primeiro tipo, como a Teutônia, custava, então, $1 \$ 333$ mil réis, e o chope era vendido ao comerciante a $1 \$ 500$ mil réis o litro, o que corresponderia a $\$ 900$ réis a garrafa. ${ }^{33} \mathrm{Não}$ admira, portanto, que fosse tão consumido: reunia suposta qualidade (a Brahma o classificava como produto de primeira qualidade), o prestígio da empresa e preço atraente. E um bom preço era um fator muito relevante em conjuntura de crise.

Dados sobre a evolução das vendas da Brahma à época são fornecidos pelos Relatórios da Diretoria ao Conselho Fiscal da empresa. Esses relatórios eram documentos de circulação interna que informavam os membros do Conselho Fiscal sobre o desempenho das vendas, calculadas a preços básicos, isso é, excluídas as margens de comercialização, transporte e imposto de consumo. Assim, o exame da evolução dos preços básicos dos diferentes tipos de cerveja entre novembro de 1928 ejaneiro de 1937 nos permite traçar o perfil da política de preços adotada pela Brahma nesse período. O preço do chope, produto do primeiro tipo, era $30 \%$ superior ao da $\mathrm{ABC}$, a cerveja mais barata da Brahma. Já o preço da cerveja de segundo tipo era $45 \%$ maior do que o da ABC, o que pode causar surpresa ao leitor, uma vez que as cervejas de segundo tipo eram produzidas a menor custo. Lembremos, porém, que elas eram comercializadas em garrafas, ao contrário do chope, vendido em barril. Desse modo, há que se considerar o peso dos custos de aquisição das garrafas, mercadoria cara, escassa e frágil, no preço final do produto.

A manutenção de preços baixos para a $\mathrm{ABC}$ relativamente aos preços outros produtos revela a estratégia adotada pela empresa para ampliar sua participação no mercado popular, mas essa decisão se mostrou problemática à época da crise. O que parecera conveniente no final de 1928 - relançar uma marca a preços acessíveis - perdera seus atrativos sob a conjuntura de retração do volume de vendas, pois não interessava à Brahma vender apenas produtos baratos para o mercado popular.

Assim, com o objetivo de ampliar seu mercado, a Brahma lançou uma nova marca no verão de 1933/1934: a Brahma Chopp. Essa nova marca visava a ampliar um determinado segmento do mercado consumidor: o consumo nas residências. O lançamento da Brahma Chopp, embora sob a roupagem de uma nova estratégia de marketing, ${ }^{34}$ deve ser

\footnotetext{
Uma garrafa de cerveja continha em média $600 \mathrm{ml}$ da bebida. A tabela de preços de venda da Brahma se refere a preços de cerveja colocada nos pontos de varejo. Como não se conhece a margem de comércio, não há como estimar o preço final pago pelo consumidor. Tabela de preços, posto $\mathrm{cm}$ domicílio, janeiro de 1931;cx. 11, port; $A B$.

${ }^{34}$ Entende-se por estratégia de marketing o conjunto de ações que visam a promover
} 
entendido, a nosso ver, como uma estratégia empresarial adotada em função de uma circunstância adversa de mercado. Ao insistir nas vendas da ABC, a Brahma poderia ter permanecido limitada aos parâmetros do mercado de baixa-renda, onde não haveria espaço para crescimento dos lucros, dada a concorrência acirrada e o limite de renda dos consumidores potenciais.

Cabe observar que as vendas de chope estavam estagnadas em todo o período analisado, como mostra o Gráfico 3. Desse modo, a Brahma Chopp buscava abrir uma nova fonte de receitas, a despeito de colocar em risco a reputação de excelência técnica da empresa ao insistir em oferecer um produto que, de fato, não poderia existir: chope em garrafa. No seu lançamento, o preço por litro da Brahma Chopp era 8,5\% mais caro do que o preço por litro de chope e $38 \%$ mais caro do que o da ABC. Se tomarmos o período entre janeiro de 1934 e janeiro de 1937 , o preço da Brahma Chopp era $39 \%$ mais caro, em média, do que o da ABC, e $11 \%$ mais caro do que o chope propriamente dito. ${ }^{35}$ Como poderia um produto mais caro alcançar a preferência dos consumidores, deslocando do mercado, inclusive, outros produtos da mesma empresa e,tudo isso, sob uma conjuntura econômica ruim? A resposta está contida na idéia de inovação. Não era exatamente uma inovação tecnológica, embora a propaganda da Brahma assim o afirmasse, mas uma inovação de produto, capaz de atrair a curiosidade dos consumidores, desejosos de experimentar a novidade no mundo das cervejas brasileiras. Eis uma propaganda da Brahma Chopp publicada na imprensa carioca, em março de 1934 , exaltando a inovação tecnológica contida no produto: ${ }^{36}$

Ótimo! Agora também há Brahma Chopp engarrafado! Eis a grande novidade que custou cinco longos anos de experiências. Parecia impossível que se pudesse, um dia, beber o afamado Brahma Chopp em garrafas! É que o chopp, pela sua própria natureza, devia sempre ser bebido, logo depois de sair da fábrica. Mas venceu a maestria dos técnicos da Brahma. E agora já existe — para satisfação

as vendas de um produto. A Brahma Chopp buscava atender à demanda por chope fora dos espaços públicos de diversão. Philip Kotler (1996), Marketing, São Paulo: Atlas.

Essa relação foi calculada a partir dos relatórios da Diretoria ao Conselho Fiscal, que informam a quantidade vendida e o valor arrecadado por tipo de cerveja. Relatórios da Diretoria ao Conselho Fiscal, caixas 06, 05, 22, AB.

Jornal A Sentinela, 5/3/1934. 
de todos - Brahma Chopp em garrafas, de gosto, cor e leveza iguais ao Brahma Chopp em barril.

Desse modo, sob o efeito da propaganda maciça, a Brahma pretendia lançar um velho produto com nova roupagem e a preços mais elevados. O resultado, esperava-se, seria o aumento das vendas. No entanto, os efeitos do lançamento da Brahma Chopp sobre os resultados das vendas não foram sentidos imediatamente, como fez crer o redator do esboço do livro dos 50 anos da empresa: ${ }^{37}$

Em janeiro de 1934, a Brahma lançou no mercado a marca de cerveja que, até esta data, alcançou a maior fama no Brasil: a Brahma Chopp, que em pouco mais de um mês conseguiu dominar a praça.

$\mathrm{Na}$ verdade, a Brahma Chopp não reduziu a presença da $\mathrm{ABC}$ no mercado da cidade do Rio de Janeiro. As vendas da Brahma Chopp alcançaram, é certo, resultados semelhantes aos do chope em barril, que manteve a receita média mensal de Rs. 536:274\$, entre janeiro de 1934 e junho de 1937, ao passo que a Brahma Chopp vendeu, em média, Rs. 503:928\$ por mês, no mesmo período. ${ }^{38}$

Em resumo, a recuperação do nível de vendas observada a partir do segundo semestre do ano se 1935 , como se vê no Gráfico 1 , se deveu às cervejas de primeira qualidade (exportação, Brahma Chopp e chope em barril) e de terceira qualidade. As cervejas de segunda qualidade mostravam então nítidos sinais de decadência. ${ }^{39}$

\section{Vendendo cerveja, vendendo idéias}

É fato que as vendas da cerveja Brahma Chopp não apresentaram de imediato os resultados apregoados pela empresa, mas a verdade é que a

\footnotetext{
Aponianwntoi de 1894-1934, cx. 95,port.; $A B$.

${ }^{38}$ As vendas da Brahma Chopp incluem as remessas para o Interior.

${ }^{39} \mathrm{Nem}$ sempre foi assim, dados de venda relativos ao período de julho de 1912 a janeiro de 1919 revelam o predomínio das cervejas de segunda qualidade nas receitas de venda da Brahma. O que parece ter havido durante os anos 1920 foi o investimento em vendas de cerveja de primeira qualidade aos fregueses do Interior. Para alcançar bons resultados nesse mercado, a Brahma precisou adotar estratégias de comercialização específicas, como a manutenção de uma equipe permanente de representantes comerciais a percorrer numerosas localidades do interior e da costa brasileira.Teresa Cristina de Novaes Marques (2003), Capital, Cerveja e Consumo de Massa, capítulo IV.
} 
campanha de lançamento do produto trouxe inovações importantes em matéria de mensagem publicitária.

Para onde quer que se voltasse, o consumidor carioca deparava com mensagens que o induziam a consumira bebida: cartazes dispostos em lugares públicos, stands da Brahma em grandes festas populares, anúncios em jornais e revistas. Após a liberação da propaganda comercial no rádio, em 1932, também esse veículo passou a ser usado na campanha promocional, atingindo um público muito maior. ${ }^{40}$ Assim, a cerveja envolvia o cotidiano da população, e seu consumo passava a ser visto como natural. Ao expor a idéia de beber cerveja com insistência - de diversas formas e em muitos lugares - , a propaganda fez parte do processo de afirmação da liderança das grandes cervejarias no mercado. Na ausência de propaganda, a demanda por cerveja no Brasil não teria, certamente, evoluído da mesma maneira.

Neste ponto, devemos retomar a questão do consumo, já anunciada na primeira seção deste ensaio. Cabe, aqui, fazer uma breve reflexão sobre os significados sociais do consumo de massa.

Estudiosos do marketing e da propaganda não vêem problemas teóricos no consumo. As pessoas consumiriam bens para satisfazer suas necessidades: desde as mais elementares, ligadas à sobrevivência, às aspirações de ordem emocional. Esses autores aplicam conceitos originados da Psicologia à sua disciplina, e basta. A eles importa apenas elaborar os procedimentos a serem cumpridos pelos profissionais que se dedicam a promover as vendas das mercadorias de uma empresa."

Mas o consumo é, simultaneamente, uma operação econômica e cultural. Buscando definir, inicialmente, qual a natureza do consumo no processo econômico, vejamos de que forma a tradição do pensamento marxiano tratou o assunto. Marx criticou seus contemporâneos por conceberem o consumo como uma etapa externa ao processo de produção. A seu ver, produção e consumo são partes integrantes de um mesmo processo e se alimentam mutuamente. Na etapa do consumo, dá-se a realização da mercadoria, a qual, finalmente, converte-se em capital monetário. Assim, na esfera da circulação, completa-se o processo

\footnotetext{
${ }^{40}$ Em março de 1932, o Governo Provisório baixou decreto autorizando e regulamentando a propaganda nas transmissões de rádio. (Decreto $\mathrm{n}^{\circ} 21.111$, de $1^{\circ} / 3 /$ 1932). Inicialmente, os comerciais podiam ocupar até $10 \%$ das transmissões. Luiz A Ferraretto (2001), Rádio: o veículo, a história e a técnica. Porto Alegre: Sagra Luzzatto.

${ }^{4}$ Veja-se, por exemplo, o livro de Philip Kotler, muito usado nas escolas de administração: Philip Kotler(1996), Marketing, São Paulo: Atlas.
} 
de reprodução do capital industrial. ${ }^{42}$ Esse é o mundo do capitalismo, o mundo da produção de coisas. Mais e mais coisas, e para quê? Para responder a necessidades, diriam os profissionais de marketing. Marx tem uma visão mais complexa sobre o processo de indução ao consumo. Afirma ele que o consumidor age sob o apelo sedutor daquele que produz, pois este produz a mercadoria e também o modo como ela deve ser consumida. Além disso, o produtor gera no consumidor a necessidade dos produtos. Segundo Marx: "a produção não produz, pois, unicamente o objeto do consumo, mas também o modo de consumo, ou seja, não só objetiva, como subjetivamente. Logo, a produção cria o consumidor". ${ }^{43}$

Entretanto, essas respostas não esgotam o problema, uma vez que a noção de necessidade apresenta dificuldades teóricas não superadas na tradição marxiana. Entende Haug que a mercadoria é concebida para atender ao que o produtor supõe sejam as necessidades do público consumidor, mas, ao mesmo tempo, o produtor elabora um conjunto múltiplo de estratégias para fazer surgir no consumidor a necessidade de consumir um determinado bem.Voltamos a indagar: existem necessidades inatas ou tudo não passa de um discurso de emulação ao consumo, concebido, deliberadamente, para realizar o valor de troca das mercadorias? $?^{44}$

De fato, não há solução satisfatória para esse problema no âmbito da tradição de pensamento marxiano, embora possamos encontrar, no próprio Marx, uma visão sutil sobre a relação entre o produtor e o consumidor: ${ }^{45}$

"Quando o consumo se liberta da sua rudeza primitiva e perde seu caráter imediato - e não o fazer seria ainda o resultado de uma

Karl Marx (1983), O Capital.São Paulo:Abril Cultural, vol.III, t. I,pág.204. [Coleção Os Economistas].

*3 Karl Marx (1974), Para a crítica da Economia Política. Coleção Os Pensadores. São Paulo: Abril Cultural, vol. XXXV, pág. 116.

${ }^{44}$ A função da valorização sempre à procura de uma resposta para a questão da realização encontra expressão justamente na aparência exagerada do valor de uso, impelindo o valor de troca contido na mercadoria ao encontro do dinheiro. Ansiosa pelo dinheiro, a mercadoria é criada na produção capitalista à imagem da ansiedade do público consumidor. Essa imagem será divulgada mais tarde pela propaganda, separada da mercadoria.Wolfgang F. Haug (1996), Crítica à Estética da Mercadoria, pág. 35.

Karl Marx (1974), Op. cit., pág. 116. 
produção que se mantivesse num estádio de primitiva rudeza - o próprio consumo, enquanto impulso, é mediado pelo objeto. A necessidade que sente deste objeto é criada pela percepção do mesmo. (...) Portanto,a produção não cria somente um objeto para o sujeito, mas também um sujeito para o objeto."

Em outros termos, para que o consumidor necessite da mercadoria, ele a deve perceber ao percorrer a cidade, ao se sentar à mesa do bar, ao abrir o jornal. O objeto de desejo deve estar visível, e essa função é cumprida, nos tempos atuais, pela propaganda. Insere-se ela, portanto, no processo de produção. No entanto, ao manipular valores e idéias afinal, trata-se de um discurso - a propaganda representa um dos elementos que compõem a face cultural do consumo. O discurso publicitário interage com os receptores da mensagem, pois os consumidores acrescentam elementos simbólicos de seu próprio punho ao ato de consumir. Isso acontece quando os consumidores incorporam a mercadoria ao seu cotidiano, conforme seu meio cultural, e revestem o consumo de rituais e significados não pretendidos, originalmente, pela propaganda, a exemplo do comportamento dos trabalhadores portugueses que freqüentavam a Festa da Penha, no Rio de Janeiro. Nessa festa, os imigrantes portugueses, que eram, em boa medida, operários como os trabalhadores nacionais, promoviam rituais de consumo regados a cerveja e vinho, como forma de expressar o seu desejo de se diferenciar dos brasileiros ali presentes. ${ }^{46}$

A propaganda é um poderoso instrumento de intervenção no domínio econômico, apresentando-se como um discurso ideológico. Daí a sua dupla natureza: é tanto um fenômeno econômico como cultural. Entretanto, Haug examina o problema segundo a acepção de ideologia corrente entre vários pensadores marxianos: como falseamento do real. Para esse autor, a propaganda manipula a consciência social, corrompe as massas e insere o cidadão no Estado como consumidor passivo. ${ }^{47}$

Encontramos até aqui algumas respostas para as funções da propaganda. Se desejarmos reunir elementos para pensar de que forma essas

\footnotetext{
${ }^{46}$ Teresa Cristina de Novaes Marques (2003), Capital, Cerveja e Consumo de Massa, capítulo VI.

A inserção das massas no Estado como consumidores oferece uma falsa relação de pertencimento, pois a verdadeira consciência dos interesses dos trabalhadores emerge da ação política em prol de ganhos salariais. [Haug (1996), Crítica à Estética da Mercadoria, apêndice.]
} 
funções se realizam, deveremos buscá-los em outros autores. Em um ensaio, Umberto Eco mapeia o sistema de referências contido na mensagem publicitária. Adverte este autor que o discurso da propaganda se reparte em soluções visuais e verbais, sendo cada uma delas submetida a convenções próprias. E, a despeito de manipular idéias de um sistema de códigos de reconhecimento convencionado, com base nos quais o receptor da mensagem formula suas expectativas, o discurso da propaganda tem por ambição causar surpresa ou, no mínimo, emoção, atraindo a atenção do consumidor para as virtudes do produto. ${ }^{48}$

Para Eco, o discurso da propaganda se vale de recursos de retórica consagrados: metáfora, hipérbole e, principalmente, a antonomásia, quando um indivíduo é tomado como representante do comportamento de todos os outros. Esses artifícios são empregados para que o receptor da mensagem identifique os códigos culturais que estão emjogo.Vários desses recursos de retórica podem ser encontrados na propaganda da Brahma Chopp, como as duas primeiras imagens mostradas mais adiante.

Se, em termos técnicos, o novo produto não trazia inovações, trazia, como novidade, a promessa de que o apreciado chope dos bares e restaurantes estava disponível, também, para o consumo doméstico. Nisso, a Brahma seguiu a tendência que já se manifestava em outros países: ampliar os espaços de consumo da cerveja. Estava em disputa a fronteira comercial do lar. Nos EUA, por exemplo, a partir de 1932, as cervejarias pretenderam ampliar o mercado alvo de seus produtos induzindo o consumo doméstico da bebida. Nos anos que se seguiram ao fim da Lei Seca, a publicidade de cerveja empregou todos os recursos de imaginação para sugerir novas formas de inserção da bebida no cotidiano dos consumidores, como lembrou o historiador Stanley Baron: ${ }^{49}$

"De qualquer forma, a tendência manifesta era a de trazer a cerveja para o lar. Isso foi feito pela propaganda, a qual deixou de mostrar os consumidores de cerveja nos bares, preferindo mostrá-los em eventos sociais comuns: ouvindo rádio, divertindo-se com amigos, na quadra de tênis ou junto à piscina."

\footnotetext{
${ }^{48}$ Eco entende por código uma estrutura elaborada sob a forma de um modelo e postulada como regra subjacente a uma série de mensagens concretas e individuais que a ela se ajustam e só em relação a ela se tornam comunicativas. Umberto Eco (1997), A Estrutura Ausente: introdução à pesquisa semiológica. São Paulo: Perspectiva, pág. 39.

${ }^{4}$ Stanley Baron (1962), Brewed in America, The History of Beer and Ale in the United States. Boston: Litte, Brown \& Co., pág. 328.
} 
No Brasil, a propaganda das cervejarias adotou a mesma estratégia de diversificar as situações sociais em que a cerveja pudesse tomar parte como elemento aglutinador das relações humanas, embora sob outras motivações.

Notoriamente, a indústria cervejeira norte-americana saíra da experiência amarga dos anos de proibição com a necessidade de encontrar novas formas e lugares para o consumo de seus produtos, uma vez que, durante os anos da campanha pró-temperança, os bares foram alvo de severa vigilância. No auge da campanha pró-temperança nos EUA, tornou-se comum grupos de ativistas acamparem em frente a bares para constranger os freqüentadores. ${ }^{50}$ Durante o período da Lei Seca, a freqüência a bares clandestinos era assunto de polícia. No Brasil, os médicos higienistas partidários da temperança não criticaram de forma tão contundente os bares e seus freqüentadores. Centraram seus esforços primordialmente na condenação das bebidas destiladas.

A campanha promocional da Brahma Chopp se valeu substantivamente da mídia impressa e, também, do rádio, após a liberação da propaganda comercial neste veículo. No rádio, a publicidade da Brahma usou a música como aliada e alcançou um público muito mais amplo. Para atingir esse propósito, a Brahma encomendou uma marchinha ao compositor Ary Barroso, com letra do jornalista Bastos Tigre. Considerando a estratégia publicitária, o lançamento da Brahma Chopp inovou ao empregar uma composição inédita, produzida especialmente para a campanha. A curiosa letra dessa música revela que a idéia de chope engarrafado sofria constestação: ${ }^{51}$

O Brahma Chopp em garrafa

Querido em todo o Brasil

Corre longe, a banca abafa

É igualzinho ao de barril

\section{(Refrão)}

Chopp em garrafa

Tem justa fama

É o mesmo chopp

Chopp da Brahma

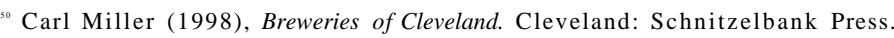

st Folheto da propaganda da Brahma Chopp, preservado no Acervo Brahma.
} 
Quando o tempo está abafado

O que o tempo desabafa

É o Brahma Chopp gelado

De barril ou de garrafa

Desde Maio até Janeiro

E de Fevereiro a Abril

Chopp da Brahma é o primeiro

De garrafa ou de barril

(Refrão)

Quem o contrário proclama

Diz uma coisa imbecil

Inveja do Chopp Brahma

De garrafa e de barril

O conteúdo das peças publicitárias adotou, com freqüência, como já observamos o recurso retórico conhecido como antonomásia. Como o comprova o anúncio publicado na revista semanal carioca $A$ Careta, em junho de 1934, onde um barman de um luxuoso hotel de Lisboa demonstra ter experimentado e aprovado o sabor da Brahma Chopp. Tão importante era a clientela dos portugueses no mercado carioca de bebidas, fossem consumidores individuais, fossem varejistas, que a Brahma previu um anúncio diretamente direcionado a esse público (Figura 1).

Outras peças publicitárias exortavam, com uma linguagem imperativa, os consumidores a procurar o novo produto nos fornecedores, além de sugerir a nova situação em que o consumo da cerveja poderia acontecer: a cena doméstica (Figura 2).

O próximo anúncio (Figura 3) apresenta uma versão técnica para a origem do novo produto: o desenvolvimento de pesquisas nos laboratórios da cervejaria.

E, por fim, mostramos a imagem da contra-propaganda da Antártica (Figura 4), que representa mais um capítulo da agressiva disputa comercial entre as duas maiores cervejarias do País. Uma rivalidade que se estendeu por décadas ao longo do século XX.

Um balanço da evolução das formas de divulgação dos produtos da Brahma desde os anos 1890 até 1934 mostra a crescente complexidade dos recursos empregados. Do velho propagandista, personagem popular, que percorria os bares consumindo cerveja, à campanha promocional 
Figura 1. Até de Portugal vêm elogios ao gosto da Brahma Chopp.

\section{Até de Portugal, vêm elogios ao gosto do Brahma CHOPP} de garrafas !...

O Sur. Yictorio Puppin, barmear do traxioio Aviz. Hotel, de Lisbôa, recebeu algumas garrafas de Brahona Chopp para experimentar e das swa upeniso iranca e positiva. Eis o que diz a peofissio. sal qque dirige o tas do hosel mais distincto da Penunsula lberica: ,

"Provei o Brahmer Chopp teibrioado - engarratado pela Cia Cervelaria Brahera, do Elo do lanelro e declaro que o achei egual -- em cpartencia * gosto, à mothor cerveja fabriceda na Europa. Albroso, sem receilo dis conteataçào que a Brahma Chopp - uma carveja da b́lima qualldade - qua, com prater, eu a servirias aos hoapedes do Avis Hotar.

$\mathrm{F}^{\prime}$ impossivel dizer mas $\mathrm{cm}$ tio pouces E palavias. Exta decharafīo ašo parte de um extrantro so assumpto "bebidas". Parte de uel entendida. $O$ cargo de "barmin" que - Ser. Puppia occupa no loxel mais aristoeratico de Porcugal é vima prova da sux ateoridade. Namialmesce, gosco - em cervejs - ó usna quente de gosto de cada pesios. Prove, entâo, una karrifa de Brahos Chopp e verifique pesso almente, quie o Brahtra Chopp de gartáfas iem uber equal to Bratuma Chopp de barril - - I moin la baszos zasios some e. melhor chogp do bisul, pela sua pareas edelicioso paladas.

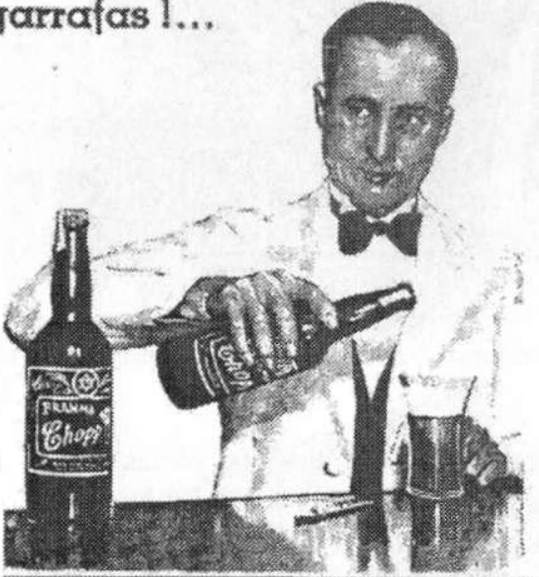

Origem: revista A Careta, 23/6/1934.

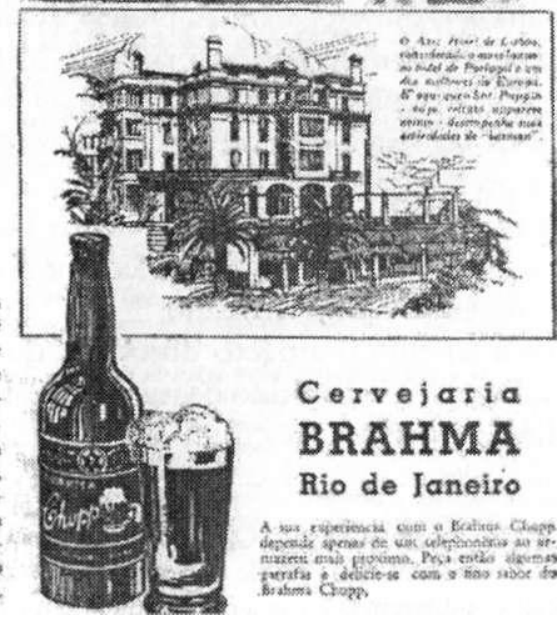




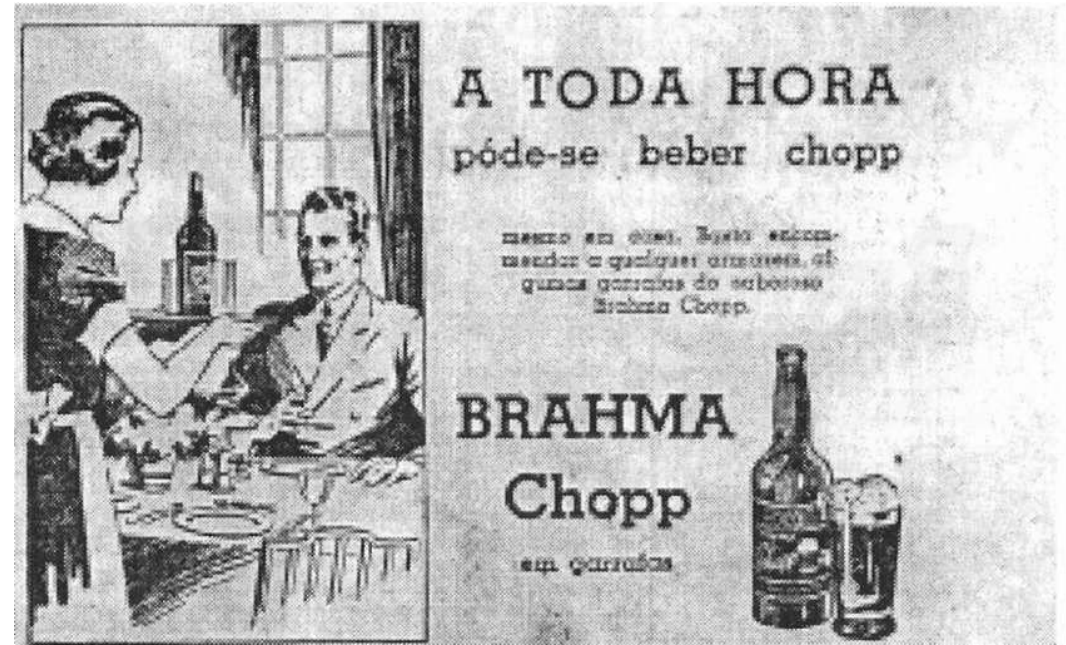

Origem: jornal Diário de São Paulo, domingo, 02/9/1934.

da Brahma Chopp nas suas várias faces (a música, os anúncios nas revistas e nos jornais, o subsídio a agremiações carnavalescas), a propaganda da Brahma ganhou sofisticação e profissionalismo. Os propósitos permaneceram os mesmos: garantir a presença da marca no cotidiano da cidade, enraizar o consumo de cerveja entre os hábitos da população, tornar perceptíveis os produtos e induzir os consumidores de bebidas alcoólicas a preferir cerveja a outras bebidas. A insistência, a repetição da mensagem, a presença da publicidade nos locais de convívio social, a participação da Brahma em grandes festividades, como exposições nacionais e festas populares, todos foram elementos da estratégia de afirmação do nome da empresa no mercado. ${ }^{52}$

Considerando o aspecto do conteúdo da mensagem publicitária, a evolução se deu no sentido de mostrar o produto em cenários cotidianos brasileiros. Longe estava o tempo em que a Brahma se apresentava ao

Segundo W. Haug (1996, Op. cit., pág. 38) a marca é a estetização da mercadoria. Torna único e revestido de identidade o produto de massa, produzido em larga escala e indiferenciado. Se a operação comercial é bem sucedida e os consumidores se tornam fiéis a uma dada marca, sustenta-se o preço de monopólio. 


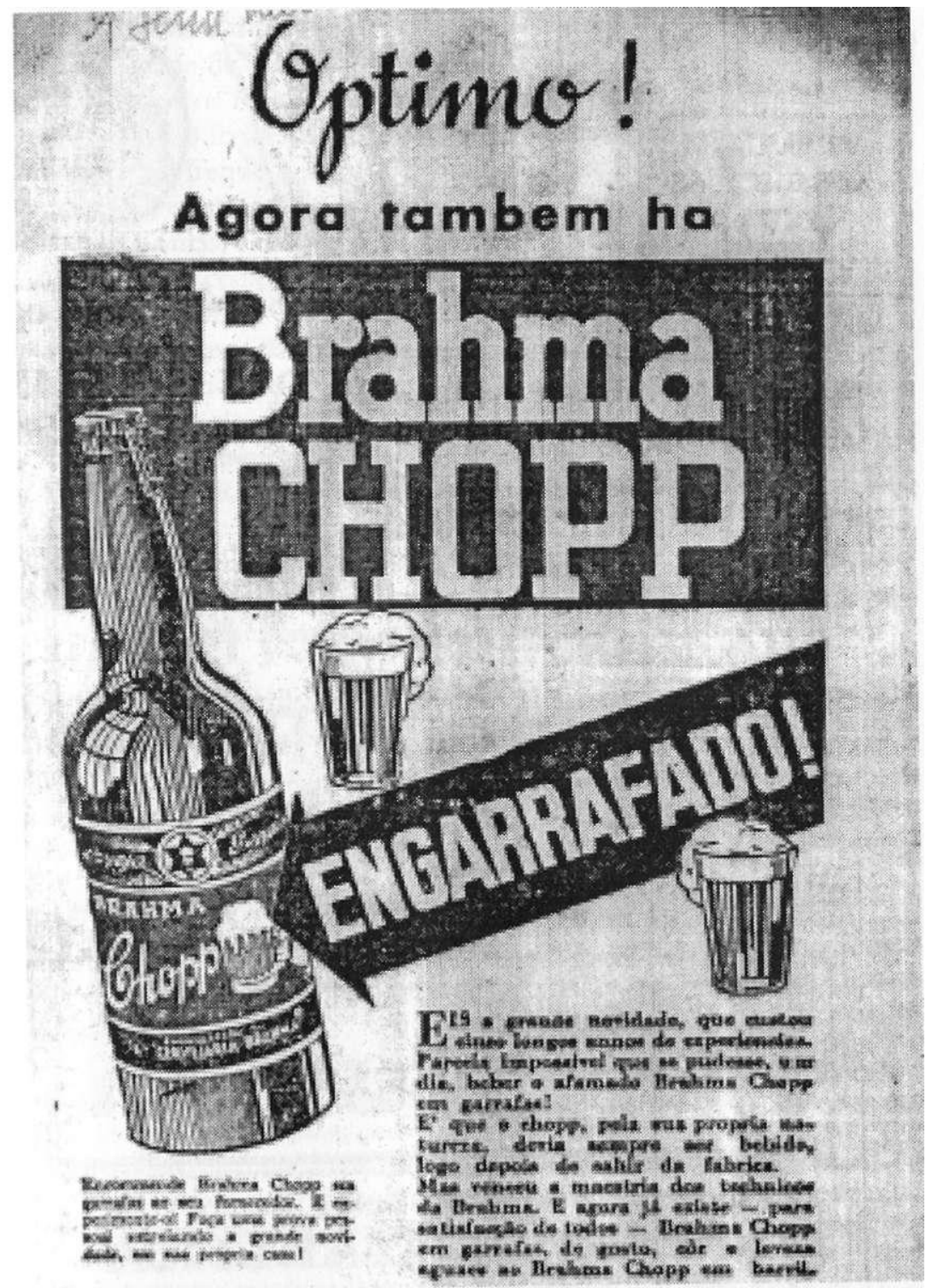

Origem: jornal $A$ Sentinela, 05/3/1934. 


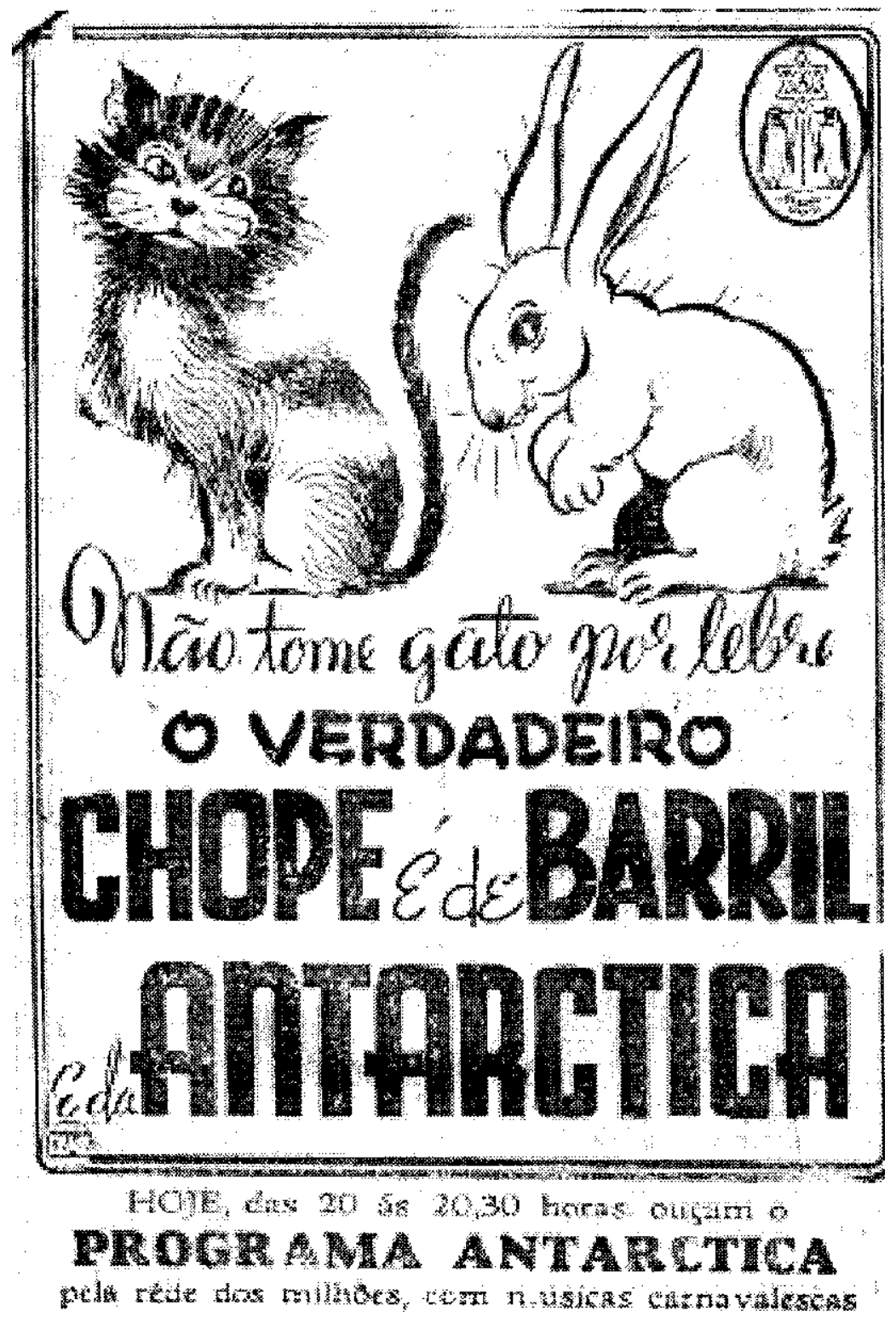


público como herdeira das tradições cervejeiras alemãs, como no folheto produzido para a Exposição Nacional de $1908 .^{53}$ Durante a Guerra, a empresa foi alvo de retaliações políticas em razão de seus vínculos com a comunidade de negócios alemã no Brasil, e, a partir de então, foram abandonados os recursos textuais e imagéticos que a relacionassem à Alemanha. Os ícones costumeiros que remetiam à tradição cervejeira européia, tão freqüentemente evocados nas peças de propaganda elaboradas até a Primeira Guerra, desapareceram. O monge medieval, a estrela de seis pontas, os ramos de lúpulo e de cevada e a fortaleza medieval deram lugar a cenas prosaicas, em que o ato de beber cerveja ocupa o papel de elemento aglutinador das relações sociais, tendo por cenário de fundo imagens da cidade do Rio de Janeiro. Ressalvemos que essa mudança é menos perceptível nos rótulos das garrafas do que nos cartazes e demais peças de propaganda impressa.

Poder-se-ia argumentar que a renovação do conteúdo faz parte do discurso publicitário, que busca encontrar novas formas para realizar seu propósito de manter o interesse do consumidor pelo produto. Mas, sem dúvida, o lançamento da cerveja Brahma Chopp representou mais do que uma mudança estética e de conteúdo, representou uma ruptura simbólica definitiva com a tradição cervejeira alemã.

\section{Considerações finais}

Há que se ressaltar o aspecto simbólico do lançamento da Brahma Chopp. Só mesmo uma empresa muito segura do seu lugar no mercado ousaria lançar um produto assim, que rompia com todos os cânones da tradição cervejeira alemã. Não há, definitivamente, chope engarrafado, e os contemporâneos tinham disso plena consciência.Tudo indica que, no limiar dos anos 1930, não convinha mais à direção da Brahma cultivar os vínculos com a tradição européia.

${ }^{5}$ Lê-se no folheto assinado pelo médico Pires de Almeida, identificado como higienista, a vinculação da Brahma ao padrão científico de produção de cerveja vigente na Alemanha:

Todas estas delicadas transformações que vão aqui resumidas, se guardam e observam no fabrico de diferentes marcas da Cervejaria Brahma, sendo que a elas presidem dois químicos de nomeada, ambos igualmente abalizados c um dos quais dirigiu, no caráter de diretor-técnico, uma das mais afamadas cervejarias da Alemanha. Dr. Pires de Almeida (1908), A Companhia Cervejaria Brahma perante a indústria, o comércio e a higiene. Rio de Janeiro: Canton \& Beyer, pág. 10. 
A situação se apresentava da seguinte maneira: havia uma grave crise de vendas e poucos recursos disponíveis para superá-la. Mesmo sob o risco de macular a reputação de excelência de seus produtos, tão cultivada nas três primeiras décadas de existência da empresa, valia a pena incentivar o consumo doméstico de chope, conquistando a fronteira do lar. Ao mesmo tempo, a Brahma amplia sua presença no mercado consumidor de maior renda, agora que a sua ABC ganhara posições no mercado popular. 